Vol. 24, No. 2, April 2021, hlm. 342-353

p-ISSN: 1410-9344; e-ISSN: 2549-5631

WARTA LPM

homepage: http://journals.ums.ac.id/index.php/warta

\title{
Peningkatan Kesadaran Kesehatan Reproduksi Perspektif Islam dan Medis bagi Remaja Pimpinan Cabang Nasyiatul Aisyiyah Ngawen Klaten
}

\author{
${ }^{1}$ Yunita Furi Aristyasari, ${ }^{2}$ Mir'atun Nisa', ${ }^{3}$ Nur Azizah Indriastuti \\ ${ }^{1}$ Program Studi Teknik Sipil, Fakultas Teknik, Universitas Muhammadiyah Yogyakarta \\ 2,3Program Studi Ilmu Keperawatan, Fakultas Kedoketaran dan Ilmu Kesehatan, Universitas Muhammadiyah \\ Yogyakarta \\ email: ${ }^{1}$ yunita.furi.aristyasari@umy.ac.id, ${ }^{2}$ miratunnisa@umy.ac.id
}

\section{Article Info}

Submitted: 8 January 2020

Revised: 2 March 2021

Accepted: 12 March 2021

Published: 21 April 2021

Keywords: adolescents, reproductive health, Islamic perspective, medical perspective
Kata kunci: remaja, kesehatan reproduksi, Islam, Medis
Abstract

Nasyiatul Aisyiyah is a women's organization that cares about reproductive health issues. Most of the members of Nasyiatul Aisyiyah Ngawen Klaten are teenagers who live in the Orphanage of Aisyiyah Ngawen Children's Social Welfare Institute. The condition allows them to become less exposed to information about reproductive health. This community service aims to raise awareness of reproductive health from medical and sharia aspects to Nasyiatul Aisyiyah youth. The method is carried out by socialization by Lecturers of Islamic Religion and Lecturers of nursing science followed by discussions and equipped booklets. Socialization and discussion were conducted face-to-face at the Meeting House of Aisyiyah Klaten Children's Social Welfare Institute. The number of participants who participated in the activity was 46 people. Socialization materials include the introduction of reproductive organs, how to keep them from medical aspects, Islamic sharia for Muslims, Islamic sharia wisdom on reproductive health. The results show an increase in the category of well-knowledgeable participants from $11.00 \%$ to $40.40 \%$ of respondents. The improvement of the knowledge aspect of the participants was dominated from the health aspect of Islamic perspective reduction. Changes in respondents' behavior are known by filling out questionnaires one week after educational exposure. Participants who had a good category in reproductive health care behavior increased from $26.10 \%$ to $33.80 \%$ of respondents. Reviewing the overall results coupled with the interest of participants, this program needs to be followed up with socialization, simulation, and training of cadres who promote healthy living and free Islamic reproductive disorders.

\footnotetext{
Abstrak

Nasyiatul Aisyiyah merupakan organisasi perempuan yang peduli dengan permasalahan kesehatan reproduksi. Sebagian besar anggota
} 
Nasyiatul Aisyiyah Ngawen Klaten merupakan remaja yang menetap di Panti Asuhan Lembaga Kesejahteraan Sosial Anak Aisyiyah Ngawen. Kondisi tersebut memungkinkan mereka menjadi kurang terpapar informasi mengenai kesehatan reproduksi. Pengabdian kepada masyarakat ini bertujuan untuk meningkatkan kesadaran kesehatan reproduksi dari aspek medis dan syariat kepada remaja Nasyiatul Aisyiyah. Metode Pengabdian kepada masyarakat dilakukan dengan sosialisasi oleh dosen agama islam dan dosen ilmu keperawatan diikuti diskusi dan dilengkapi booklet sebagai bahan ajar. Sosialisasi dan diskusi dilakukan dengan tatap muka langsung di Gedung Pertemuan Lembaga Kesejahteraan Sosial Anak Aisyiyah Klaten. Jumlah peserta sekaligus responden yang mengikuti kegiatan 46 orang. Materi sosialisasi meliputi pengenalan organ reproduksi, cara menjaganya dari aspek medis, syariat-syariat Islam untuk muslimah, dan hikmah syariat Islam terhadap kesehatan reproduksi. Parameter efektivitas penyuluhan diindikasi dengan meningkatnya pengetahuan dan perilaku peserta dalam menjaga kesehatan organ reproduksi melalui perhitungan kuesioner. Hasil edukasi menunjukkan penurunan jumlah peserta yang memiliki pengetahuan kesehatan reproduksi kategori kurang dan cukup. Sebaliknya, kategori peserta berpengetahuan baik menunjukkan peningkatan dari $11.00 \%$ menjadi $40.40 \%$ responden. Peningkatan aspek pengetahuan peserta didominasi dari aspek kesehatan repoduksi perspektif Islam. Perubahan perilaku responden diketahui dengan melakukan pengisian kuesioner dua minggu pasca pemaparan edukasi. Pesertayang memiliki kategori baik dalam perilaku menjaga kesehatan reproduksi meningkat dari $26.10 \%$ menjadi $33.80 \%$ responden. Meninjau keseluruhan hasil tersebut ditambah dengan minat peserta, maka program ini perlu ditindaklanjuti dengan sosialisasi tentang gangguan reproduksi, simulasi deteksi dini, dan pelatihan kader yang mempromosikan hidup sehat dan Islami bebas gangguan reproduksi.

\section{PENDAHULUAN}

Pengabdian kepada Masyarakat ini dilakukan di Kecamatan Ngawen Klaten Provinsi Jawa Tengah Republik Indonesia. Jumlah penduduk remaja (menurut World Health Organization (WHO) adalah kelompok yang berada di rentang usia 10-19 tahun) yang berdomisili di Kecamatan Ngawen dari kelompok jenis kelamin perempuan berjumlah 3.433 jiwa. Sementara jika merujuk kelompok umur menurut (BKKBN, 2013), yang dimaksud dengan kelompok remaja adalah kelompok di rentang usia 10-24 tahun. Berdasarkan rentang usia ini, kelompok remaja dari jenis kelamin wanita yang berdomisili di Kecamatan Ngawen berjumlah 5.063 jiwa.
Sebagian dari jumlah tersebut terlibat aktif mengikuti organisasi di wilayah tersebut. Di antara organisasi kewanitaan yang masih eksis dan diikuti sebagian masyarakat remaja Ngawen adalah Nasyiatul Aisyiyah. Prinsip gerakan Nasyiatul Aisyiyah adalah organisasi otonom dan kader Muhammadiyah yang merupakan gerakan putri Islam yang bergerak dalam bidang keagamaan, kemasyarakatan, dan keputrian (Nasyiatul 'Aisyiyah, 2016). Bidang keorganisasian Nasyiatul Aisyiyah meliputi bidang keorganisasian, bidang kaderisasi, bidang keislaman, dan bidang kemasyarakatan. Pimpinan Cabang Nasyiatul Aisyiyah (PCNA) Ngawen Klaten berjumlah kurang lebih 70 orang yang meliputi remaja dan dewasa dari usia 15 tahun hingga kurang dari 40 tahun. Keanggotaan 
tersebut berasal dari berbagai desa yang berada di wilayah kecamatan Ngawen. Namun, sebagian anggota dan kader Pimpinan Cabang Nasyiatul Aisyiyah (PCNA) Ngawen berasal dari panti asuhan Lembaga Kesejahteraan Sosial Anak (LKSA) Aisyiyah Ngawen Klaten. Hal ini merupakan usaha Aisyiyah melalui Nasyiatul Aisyiyah untukmemberdayakan para perempuan sejak tingkat remaja untuk aktif berorganisasi. Hal ini sesuai dengan cita-cita Nasyiatul Aisyiyah yaitu untuk berbagi sumber pembelajaran untuk keluarga (family learning center), antara lain berupa lembaga yang memberikan perlindungan dan pendampingan terhadap permasalahan anak dan perempuan (Nasyiatul 'Aisyiyah, 2016). Pemberdayaan terhadap para remaja yang bertempat tinggal di Panti Asuhan LKSA Aisyiyah Ngawen Klaten juga merupakan bagian dari isu strategis Nasyiatul Aisyiyah, yaitu pendampingan anak dan perempuan putus sekolah, perempuan miskin baik secara ekonomi, keterampilan maupun spiritual, dengan berbasis lokalitas (Nasyiatul 'Aisyiyah, 2016). Hal ini sekaligus membuktikan bahwa Nasyiatul Aisyiyah merupakan organisasi perempuan (sex-based) dengan basis kesukarelawanan (voluntary-based) sekaligus berasaskan Islam (religious-based) (Annisa, 2012).

Beberapa strategi yang dilakukan dalam memberdayakan anggota Pimpinan Cabang Nasyiatul Aisyiyah (PCNA) Ngawen Klaten adalah melaksanakan kegiatan seperti memajukan aspek pendidikan, keorganisasian, keagamaan, dan kesehatan. Namun, dari hasil wawancara dengan Ketua PCNA Ngawen, yaitu Ayunda Ofik Anggraini, program yang selama ini diselenggarakan oleh PCNA Ngawen mengalami kendala, yaitu kurangnya minat dan partisipasi anggota untuk mengikuti acara yang diselenggarakan oleh Pengurus Pimpinan Cabang Nasyiatul Aisyiyah (PCNA) Ngawen. Jika dirunut akar permasalahan tersebut adalah karena program Pimpinan Cabang Nasyiatul Aisyiyah (PCNA) Ngawen yang dianggap kurang menarik atau kurang menyentuh aspek-aspek yang menjadi kebutuhan perempuan sehingga kurang termotivasi untuk mengikuti kegiatan-kegiatan Pimpinan Cabang Nasyiatul Aisyiyah (PCNA) Ngawen. Hal ini ditegaskan oleh Ryan \& Deci dalam (Cahyorinartri, 2018) yang membedakan tipe motivasi berdasarkan perbedaan alasan dan tujuan yang diberikan untuk melakukan suatu tindakan. Perbedaan paling mendasar antara motivasi intrinsik dan motivasi ekstrinsik adalah bahwa motivasi intrinsik mengacu pada pengertian seseorang mengerjakan sesuatu karena ketertarikan yang muncul dalam dirinya, atau karena pada dasarnya dia senangi. Sementara, motivasi ekstrinsik adalah motivasi yang mengacu pada seseorang untuk melakukan sesuatu karena mengarah pada sesuatu yang akan dia dapatkan. Pada level tertinggi dari motivasi ekstrinsik, individu berperilaku karena ia menyadari pentingnya aktivitas tersebut untuk dirinya. Dalam hal ini, rendahnya partisipasi anggota Pimpinan Cabang Nasyiatul Aisyiyah (PCNA) Ngawen karena kurangnya faktor-faktor ekstrinsik yang mampu mendorong motivasi mereka untuk mengikuti program kegiatan yang diselenggarakan Pimpinan Cabang Nasyiatul Aisyiyah (PCNA) Ngawen. Jika mengacu apa yang dikemukakan oleh Ryan \& Deci tersebut, maka pengurus Pimpinan Cabang Nasyiatul Aisyiyah (PCNA) Ngawen dirasa perlu untuk untuk menyelenggarakan suatu program yang mengakomodasi kepentingan dan kebutuhan anggotanya. Di antara aspek yang cukup mendapat perhatian lebih bagi kaum perempuan adalah permasalahan kesehatan reproduksi.

Dari hasil observasi terhadap program yang telah dilakukan oleh Pimpinan Cabang Nasyiatul Aisyiyah (PCNA) sebelumnya, yaitu seminar kesehatan reproduksi, terdapat antusiasme yang besar oleh para peserta dimulai dari peserta yang hadir hingga banyaknya peserta yang aktif yang bertanya. Hal ini ditunjukkan dengan persentase anggota NA yang hadir cukup besar dari kegiatan sebelumnya, yaitu Total 39 peserta merupakan 90,7\% (39/43) dari anggota Pimpinan Cabang Nasyiatul Aisyiyah (PCNA). Sementara, hasil wawancara dengan sekretaris Pimpinan Cabang Nasyiatul Aisyiyah (PCNA) Ngawen, May Mukhlishoh mengatakan bahwa kegiatan-kegiatan PCNA Ngawen biasanya hanya dihadiri paling banyak kira-kira 50\%-60\%. Dari kegiatan tersebut, dapat diketahui animo para perempuan sangat besar terhadap persoalan reproduksi. Apalagi hal ini didukung dengan banyaknya permasalahan-permasalahan yang menyangkut organ reproduksi wanita, seperti keputihan, masalah haid, kanker serviks, organ intim mengalami bau tidak sedap, dan sebagainya. 
Dari pertimbangan mengenai hal tersebut, maka dirasa perlu melakukan suatu kegiatan serupa dengan tujuan untuk memicu motivasi para anggota Pimpinan Cabang Nasyiatul Aisyiyah (PCNA) dalam berkegiatan sekaligus memberikan pemahaman mengenai kesehatan reproduksi sebagai kelanjutan dari program sebelumnya. Namun, sasaran pendidikan kesehatan reproduksi dalam pengabdian masyarakat kali ini lebih kepada kelompok remaja dengan beberapa pertimbangan sebagai berikut: 1) mengingat sebagian anggota dari Pimpinan Cabang Nasyiatul Aisyiyah (PCNA) Ngawen berasal dari kalangan remaja dan kader-kader yang dibina pun sebagian besar dari kelompok usia tersebut; 2) kelompok remaja menjadi kelompok rentan dan perlu mendapat perhatian serius. Hal ini didukung dengan beberapa karakteristik remaja yaitu memiliki keingintahuan yang besar, menyukai petualangan dan tantangan serta berani menanggung risiko atas perbuatannya tanpa didahului oleh pertimbangan yang matang (Fitriana \& Siswantara, 2018); dan 3) para remaja yang tergabung dalam Pimpinan Cabang Nasyiatul Aisyiyah (PCNA) Ngawen sebagian tinggal di panti Asuhan. Sebagian dari mereka berasal dari keluarga tidak mampu yang tidak memiliki akses informasi melalui gadget, sebagaimana diperoleh oleh teman-teman sebaya yang lain. Terkait dengan hal tersebut, (Sinaga et al., 2020) bahwa semakin berat tingkat keterpaparan remaja terhadap media informasi KRR, semakin tinggi pula persentase tingkat pengetahuan KRR, sebaliknya semakin ringan keterpaparan media informasi KRR remaja maka semakin rendah pula tingkat pengetahuan KRRnya. Sementara remaja di luar panti yang memiliki gadget bukan tidak mungkin mendapat informasi yang negatif karena dampak lain dari gadget adalah tampilantampilan yang mengandung unsur pornografi (Iryanti \& Rachmawati, 2019).

Pendidikan kesehatan reproduksi bagi remaja dirasa penting karena masa tersebut merupakan masa yang rentan mengalami permasalahan-permasalahan yang berkaitan dengan kesehatan reproduksi. Menurut BKKBN (2013) remaja mengalami pertumbuhan dan perkembangan pesat pada aspek fisik, psikologis, dan juga intelektual. Proses pertumbuhan dan perkembangan biologis tentu mempengaruhi pula perkembangan dalam organ-organ reproduksi. Organ-organ reproduksi inilah yang menjalankan fungsi-fungsi reproduksi manusia. Apabila organ-organ reproduksi tersebut tidak dirawat dan dijaga dengan baik, maka dapat menyebabkan berbagai masalah di kemudian hari. Terutama para remaja sendiri bukan tidak mungkin akan mengalami masalah-masalah tersebut. Hal ini sebagaimana diungkapkan oleh (Hasanah, 2017) bahwa permasalahan kesehatan reproduksi pada remaja dapat dikelompokkan sebagai berikut: (1) perilaku berisiko, (2) kurangnya akses pelayanan kesehatan, (3) kurangnya informasi yang benar dan dapat dipertanggungjawabkan, (4) banyaknya akses pada informasi yang salah tanpa tapisan, (5) masalah PMS termasuk infeksi HIV/AIDS, (6) tindak kekerasan seksual, seperti pemerkosaan, pelecehan seksual dan transaksi seks komersial, (7) kehamilan dan persalinan usia muda yang berisiko kematian ibu dan bayi, dan (8) kehamilan yang tak dikehendaki, yang sering kali menjurus kepada aborsi yang tidak aman dan komplikasinya. Menurut Biran sebagaimana dikutip oleh (Hasanah, 2017) kehamilan remaja kurang dari 20 tahun berisiko kematian ibu dan bayi 2-4 kali lebih tinggi dibanding ibu berusia 20-35 tahun. Penyebab mendasar dari keadaan tersebut adalah: (a) rendahnya pendidikan remaja, (b) kurangnya keterampilan petugas kesehatan, dan (c) kurangnya kesadaran semua pihak akan pentingnya penanganan kesehatan remaja. Dengan adanya permasalahanpermasalahan tersebut, maka para remaja, terutama remaja perempuan dituntut benarbenar memperhatikan kesehatan reproduksinya. Hal ini ditegaskan oleh (Dwiandriani \& Nasrullah, 2017) bahwa kebanyakan orang tua memang tidak termotivasi untuk memberikan informasi mengenai seks dan kesehatan reproduksi kepada remaja sebab mereka takut hal itu justru akan meningkatkan terjadinya hubungan seks pranikah. Padahal, anak yang mendapatkan pendidikan seks dari orang tua atau sekolah cenderung berperilaku seks yang lebih baik daripada anak yang mendapatkannya dari orang lain.

Dalam ajaran agama Islam, aturan hukum terkait dengan hak reproduksi menunjukkan secara jelas bahwa kaum perempuan didudukkan dalam posisi yang terbatas dan 
sempit karena ketatnya ajaran agama (Rizal, 2015). Di antara ajaran-ajaran Islam yang memiliki hikmah kebaikan terutama dalam permasalahan kesehatan reproduksi, di antaranya adalah masalah thaharah, masalah haid, istihadhah, aturan menutup aurat dan sebagainya. Bagi seorang muslim mengamalkan syariat Islam adalah suatu kewajiban yang harus dipenuhi. Namun, belum tentu seorang muslim memahami setiap hikmah yang terkandung dalam setiap ajaran dan syariat Islam tersebut. Seperti contohnya masalah thaharah yang memiliki hikmah terhadap kesucian dan kebersihan individu. Perilaku hidup bersih dan sehat seharusnya di lakukan oleh setiap orang terutama remaja karena masa remaja merupakan salah satu periode penting dalam kehidupan di mana remaja tumbuh dan berkembang (Djunaedi \& Listyandini, 2020). Berkaca dari hal ini, maka penting untuk memberikan edukasi kepada masyarakat, terutama remaja putri Islam mengenai permasalahan kesehatan reproduksi, baik dari perspektif kesehatan dan juga perspektif Islam karena ajaran Islam yang bersifat syumuliyah memberikan perhatian yang besar terhadap persoalan kesehatan dan kesucian pemeluknya. Tidak terkecuali para peserta karena mereka adalah remaja yang rentan terhadap gangguan reproduksi sekaligus pelajar dan kader Pimpinan Cabang Nasyiatul Aisyiyah (PCNA) yang diharuskan memiliki pengetahuan dan nilai-nilai Islam serta menerapkannya dalam kehidupan seorang muslim. Dari pemaparan di atas, maka pengabdian masyarakat ini dilakukan dengan tujuan untuk: 1) meningkatkan kesadaran kesehatan reproduksi yang komprehensif dengan memberikan edukasi yang integratif antara ilmu medis dan ilmu agama kepada anggota Pimpinan Cabang Nasyiatul Aisyiyah (PCNA) Ngawen, khususnya remaja di Panti Asuhan LKSA Aisyiyah; 2) meningkatkan motivasi anggota PCNA Ngawen dengan menyesuaikan kebutuhan mereka sebagai kaum perempuan sekaligus

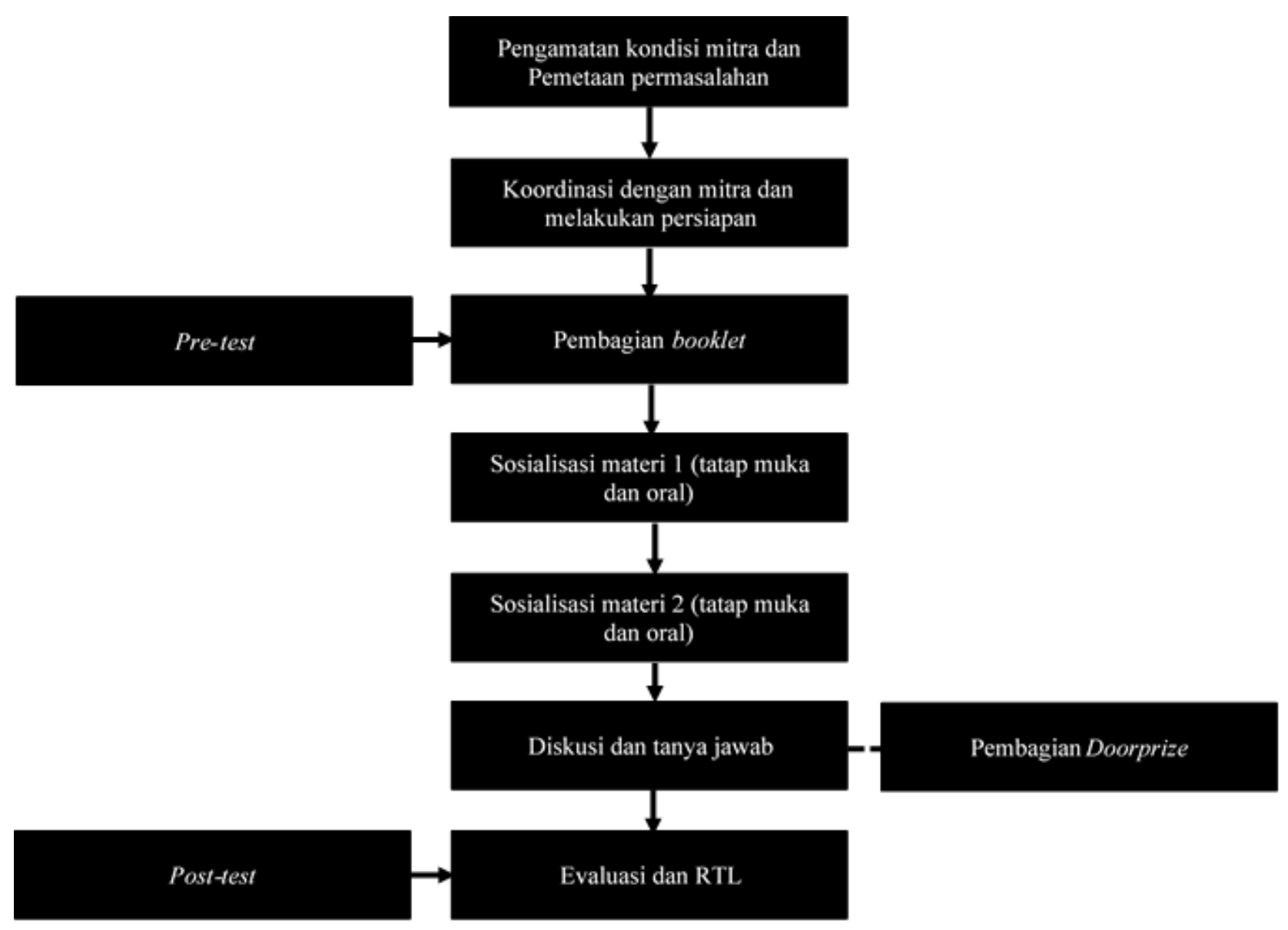

Gambar 1. Bagan Alur Metode Pengabdian Masyarakat 
sebagai bentuk penyelenggaraan shilaturrahmi putri-putri keluarga Muhammadiyah-Aisyiyah (Shobahiya, 2016).

\section{METODE}

Untuk menjawab permasalahan di atas, Tim bekerja sama dengan mitra, yaitu pengurus harian PCNA Ngawen untuk memecahkan permasalahan yang dihadapi. Adapun metode pelaksanaan meliputi langkah-langkah yang dituangkan dalam skema pada Gambar 1.

Penjelasan lebih detail mengenai metode pelaksanaan pengabdian masyarakat yang terdapat dalam bagan di atas akan dijelaskan sebagai berikut:

a. Tahap Observasi. Observasi dilaksanakan pada bulan Oktober 2019 bertepatan dengan seminar keputihan yang diadakan oleh PCNA Ngawen dengan salah satu dokter bedah dan kandungan dari RSIA Aisyiyah Klaten, yaitu dr. Ivanna Beru Brahmana, Sp.OG. Dalam seminar tersebut tampak peserta yang sangat antusias untuk mengikuti kegiatan seminar tersebut dikarenakan materi yang menarik dan sangat mengena dengan kebutuhan para kaum perempuan. Pada saat kegiatan tersebut, Tim menghubungi pihak penyelanggara untuk melakukan wawancara. Dari hasil kontak dan wawancara dengan ketua panitia, yaitu Ayunda Ofik Anggraini didapatkan gambaran besar mengenai PCNA Ngawen dan permasalahan yang terdapat di dalamnya. Dari hasil observasi dan wawancara tersebut, maka permasalahan mitra dapat dipetakan dengan jelas.

b. Tahap Persiapan. Persiapan dilakukan setelah mendapat kesediaan mitra untuk pengabdian masyarakat. Tahap persiapan meliputi pembuatan proposal, koordinasi dengan mitra mengenai waktu dan tempat pelaksanaan serta hal-hal yang diperlukan selama kegiatan. Dari koordinasi dengan mitra tersebut, didapatkan kesepakatan waktu dan tempat kegiatan akan dilaksanakan. Dalam tahap ini, Tim pengabdian kepada masyarakat juga mempersiapkan booklet dengan menyusun sendiri isi booklet tersebut. Booklet berjudul "Kesehatan Reproduksi Wanita Perspektif
Islam dan Kedokteran" dibagikan kepada peserta. Buku tersebut terdiri dari 49 halaman dengan cover ditunjukkan pada Gambar 9. dengan pembagian tugas sebagai berikut: 1) Ibu Noor Azizah Indriastuti dari Prodi Studi Ilmu Keperawatan menyusun materi tentang kesehatan reproduksi dari aspek medis. 2) Ibu Mir'atun Nisa' dari Prodi Studi Ilmu Keperawatan yang membidangi Al-Islam Kemuhammadiyahan menyusun materi kesehatan reproduksi dari aspek syariat Islam, dan 3) Yunita Furi Aristyasari dari Prodi Teknik Sipil Bidang Al-Islam Kemuhammadiyahan melakukan editing dan menambahkan materi tentang fiqih perempuan.

c. Tahap Pelaksanaan (Pengisian Kuesioner). Pelaksanaan dimulai dengan pengisian kuesioner, yaitu dengan metode pre-test dan diakhiri dengan post-test. Untuk mengetahui kesadaran kesehatan reproduksi pada remaja dengan indikator tingkat pengetahuan dan pengamalan (perilaku), maka dilakukan pengisian kuesioner yang diisi sebelum kegiatan (pre-test) dan sesudah kegiatan (post-test). Khusus untuk mengukur aspek perilaku, tim pengabdian masyarakat melakukan post-test dua minggu setelah edukasi. Kuesioner berjumlah 10 soal. Pokok-pokok isi kuesioner meliputi:

1) Pengetahuan kesehatan reproduksi menurut ilmu medis, meliputi pengetahuan tentang organ-organ reproduksi dan fungsinya serta gejalagejala organ reproduksi mengalami gangguan atau masalah.

2) Pengetahuan mengenai kesehatan reproduksi perspektif Islam, meliputi adakah hubungan syariat Islam dengan kesehatan reproduksi, haid, dan istihadhah serta ruang lingkupnya.

3) Sikap dan perilaku menjaga kesehatan organ reproduksi sesuai aturan ilmu medis.

4) Pengamalan anjuran-anjuran Islam, terkait thaharah dan adab berpakaian.

d. Tahap Pelaksanaan (Pembagian Booklet). Setelah mengisi kuesioner pre-test dilakukan pembagian booklet yang berisi

Warta LPM, Vol. 24, No. 2, April 2021 
penjelasan tentang kesehatan reproduksi baik dari sisi medis dan sisi ajaran Islam. Poin-poin yang terdapat dalam booklet tersebut adalah: pengertian kesehatan reproduksi, fungsi-fungsi dari organ reproduksi, upaya menjaga dan mencegah organ reproduksi dari berbagai penyakit, dalil-dalil, dan aturan Islam yang memiliki hikmah bagi kesehatan reproduksi wanita.

\section{e. Tahap Pelaksanaan (Sosialisasi).}

Sosialisasi untuk meningkatkan kesadaran sehat reproduksi dilakukan oleh dua narasumber dalam satu hari, yaitu pada hari Minggu, 09 Februari 2020. Narasumber pertama menjelaskan tentang kesehatan reproduksi dari perspektif ilmu medis. Narasumber kedua menjelaskan tentang kesehatan reproduksi dari perspektif Islam. Sosialisasi berupa penjelasan oleh narasumber disertai dengan tampilan slide berupa gambar dan video. Sosialisasi kemudian diikuti dengan diskusi dan tanya jawab. Pokok-pokok sosialisasi dan diskusi meliputi:

1) Kesehatan Reproduksi perspektif ilmu kesehatan: peserta diajak berdiskusi dengan dipandu oleh seorang fasilitator untuk mengenali kesehatan reproduksi, organ-organ reproduksi, dan gangguan-gangguan yang mungkin dialami oleh organ-organ tersebut. Dalam diskusi ini fasilitator berusaha memberikan pengenalan dan pemahaman kepada peserta tentang beberapa organ-organ reproduksi dan fungsinya melalui slide yang berisi teks, gambar dan video. Selanjutnya, peserta diminta menyampaikan keluhankeluhan atau gangguan-gangguan apa yang pernah dialaminya untuk kemudian didiskusikan solusinya oleh fasilitator.

2) kesehatan reproduksi perspektif islam: hikmah ajaran islam bagi kesehatan, hubungan ajaran islam dengan kesehatan reproduksi, dan penjelasan mengenai hikmah ajaranajaran Islam yang berkaitan dengan kesehatan reproduksi. Setelah fasilitator/narasumber memaparkan mengenai ajaran Islam tersebut, peserta dipersilakan bertanya kepada narasumber mengenai ajaran-ajaran Islam tersebut.

f. Tahap Pelaksanaan (Diskusi). Pada saat kegiatan diskusi dan tanya jawab, panitia memberikan doorprize bagi peserta yang aktif. Tujuan pemberian doorprize ini ditujukan supaya menarik antusiasme peserta dan sebagai motivasi bagi peserta untuk mengikuti kegiatan-kegiatan PCNA Ngawen selanjutnya.

g. Tahap Evaluasi. Evaluasi dilaksanakan setelah tahap pelaksanaan pengabdian masyarakat berakhir. Evaluasi dilakukan untuk menilai pengaruh pelaksanaan kegiatan dalam mengatasi permasalahan yang ada pada mitra. Keberhasilan kegiatan pengabdian masyarakat ini dinilai dari adanya peningkatan peserta yang masuk dalam kategori berpengetahuan dan berperilaku baik dalam menjaga kesehatan reproduksi dengan nilai capaian $70 \%$ dari seluruh peserta. Di samping itu, evaluasi juga dilakukan untuk menemukan rencana tindak lanjut yang akan dilaksanakan oleh Tim pengabdian masyarakat.

\section{HASIL DAN PEMBAHASAN}

\section{Deskripsi Pengetahuan dan Perilaku Peserta terhadap Kesehatan Reproduksi}

Kegiatan pengabdian masyarakatini dimulai dengan melaksanakan kuesioner, yaitu dengan cara meminta setiap peserta untuk mengisi lembar pre-test. Jumlah peserta yang mengisi pre-test berjumlah 46 orang peserta yang terdiri dari remaja putri PCNA Ngawen dan peserta lain dari luar. Gambar berikut menunjukkan situasi pengisian kuesioner oleh para peserta.

Dari hasil analisis kuesioner pre-test dengan post-test terhadap 46 peserta terdapat peningkatan pengetahuan para peserta dari perspektif Islam dan juga perspektif medis setelah mengikuti kegiatan edukasi dengan rincian pada Tabel 1 .

Persentase peningkatan pengetahuan peserta tersebut dapat diamati dari grafik pada gambar 3. 


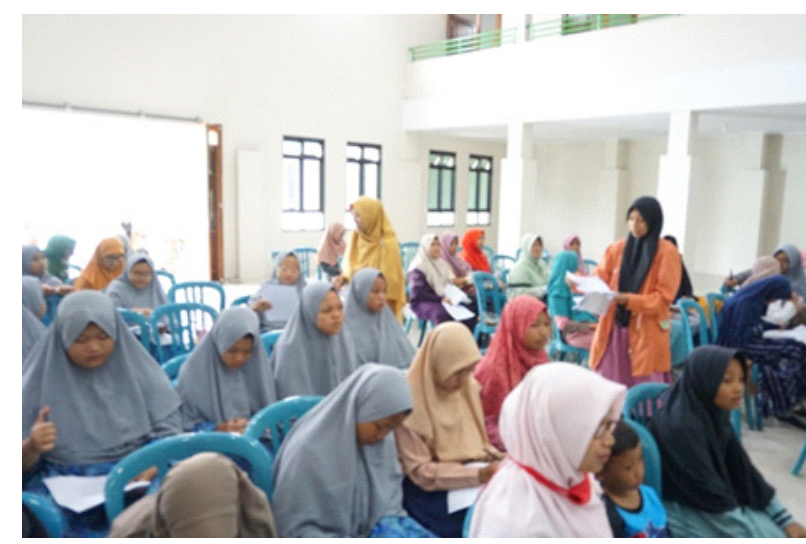

Gambar 2. Pengisian Kuesioner Pre-Test

Tabel 1. Hasil Perhitungan Pre-test dan Post-test Aspek Peningkatan Pengetahuan

\begin{tabular}{ccc}
\hline Kategori & Pre-test & Post-test \\
\hline Kurang & $12.50 \%$ & $1 \%$ \\
Cukup & $76.50 \%$ & $58.60 \%$ \\
Baik & $11 \%$ & $40.40 \%$ \\
Total & $100 \%$ & $100 \%$ \\
\hline
\end{tabular}

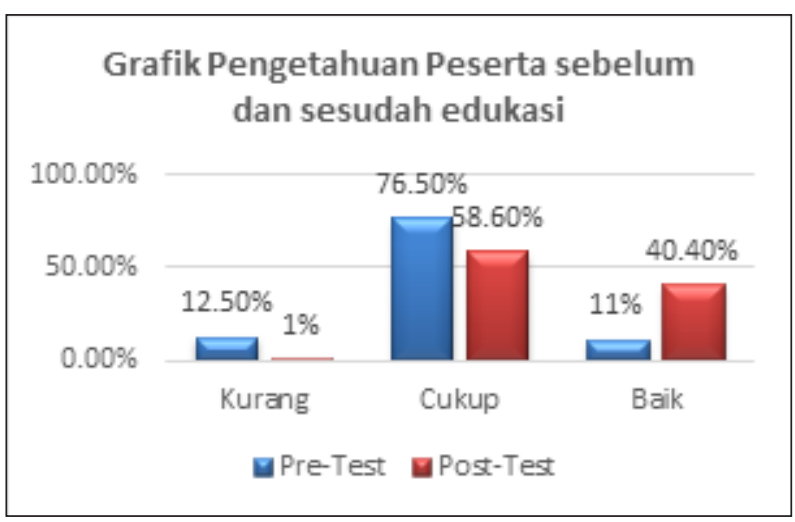

Gambar 3. Grafik Persentase Pengetahuan

Kesehatan Reproduksi bagi Remaja

Dari tabel dan grafik hasil pre-test dan post-test di atas, dapat diketahui bahwa hasil post-test pada kategori pengetahuan kurang dan cukup mengalami penurunan jumlah peserta dibandingkan pada saat pre-test. Sebaliknya, jumlah peserta yang memiliki pengetahuan dalam kategori Baik mengalami selisih peningkatan sebesar $29.4 \%$.

Setelah dilakukan edukasi jumlah peserta yang memiliki pengetahuan kategori Cukup tetap berada di rangking tertinggi dibandingkan jumlah peserta yang memiliki pengetahuan kategori Baik. Meskipun kegiatan serupa pernah diadakan sebelumnya, yaitu seminar kesehatan reproduksi, tetapi ternyata peningkatan pengetahuan untuk berada dalam kategori Baik belum cukup signifikan. Hal ini dapat disebabkan oleh kurangnya waktu untuk memberikan edukasi selama pengabdian masyarakat dengan materi yang sangat banyak dan padat. Di samping itu, kurangnya media pendukung yang dimanfaatkan langsung oleh peserta untuk menambah pengetahuan, seperti gadget juga menyebabkan jumlah peserta kategori Baik lebih sedikit dari peserta kategori cukup.

Peningkatan pengetahuan peserta terhadap kesehatan reproduksi lebih banyak dari aspek perspektif Islam. Selama mengikuti kegiatan PCNA Ngawen, para remaja tersebut belum pernah memeroleh materi pendidikan kesehatan reproduksi dalam perspektif Islam. Peningkatan pengetahuan yang didapatkan oleh mayoritas peserta meliputi beberapa hal sebagai berikut:

1) Anatomi organ reproduksi

2) Fungsi masing-masing organ reproduksi

3) Bagian dari Organ Reproduksi yang sering terkena penyakit

4) Macam-macam gangguan dan kelainan reproduksi

5) Upaya pencegahan penyakit yang menyerang organ reproduksi dari aspek nutrisi makanan

6) Cara yang benar dalam membersihkan kemaluan

7) Manfaat thaharah untuk kesehatan reproduksi

8) Manfaat pakaian yang syar'i untuk kesehatan reproduksi

9) Hikmah dilarang berzina dan dianjurkannya menikah

10) Aturan-aturan Islam terkait haid dan istihadah

11) Perbedaan antara wadi, madzi dan mani

Sementara, hasil perbandingan antara pretest dan post-test untuk mengetahui peningkatan sikap dan perilaku remaja dalam menjaga kesehatan reproduksi dapat dilihat dalam Tabel 2.

Persentase peningkatan aspek sikap dan perilaku juga dapat diamati dalam grafik pada Gambar 4. 
Tabel 2. Hasil Perhitungan Pre-test dan Post-test Aspek Peningkatan Sikap dan Perilaku

\begin{tabular}{ccc}
\hline Kategori & Pretest & Post-test \\
\hline Kurang & $1 \%$ & $0.60 \%$ \\
Cukup & $72.90 \%$ & $65.60 \%$ \\
Baik & $26.10 \%$ & $33.80 \%$ \\
Total & $100 \%$ & $100 \%$ \\
\hline
\end{tabular}

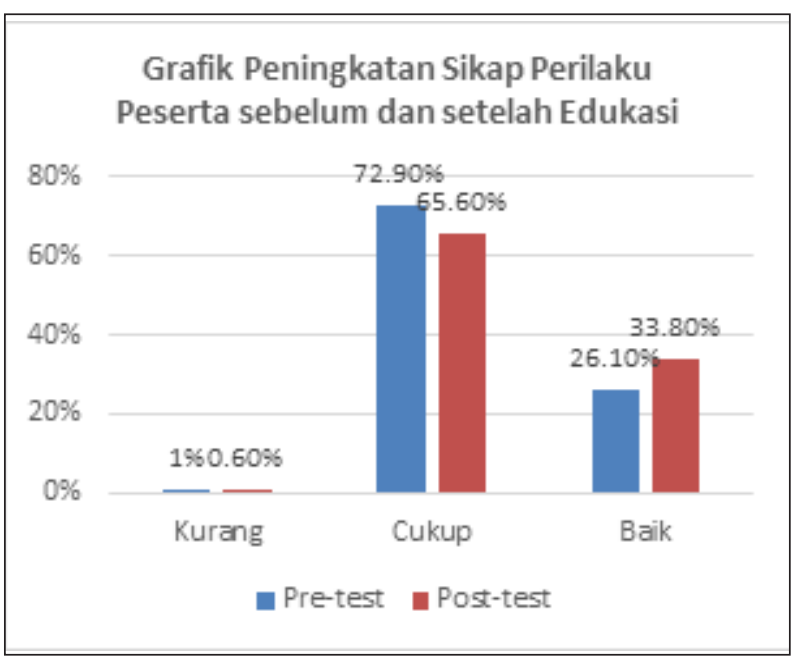

Gambar 4. Grafik Persentase Sikap dan Perilaku kesehatan reproduksi bagi remaja

Dari diagram tersebut, dapat dilihat dengan jelas bahwa perilaku dalam menjaga kesehatan reproduksi dengan kategori kurang dan cukup mengalami penurunan masing-masing sebesar 0,4\% dan 7,3\%. Sebaliknya, sikap dan perilaku para peserta remaja dalam menjaga kesehatan reproduksi dengan kategori Baik mengalami selisih peningkatan sebesar 7,7\%. Hasil tersebut menunjukkan bahwa sikap dan perilaku yang baik dalam menjaga kesehatan reproduksi belum sepenuhnya dilakukan oleh seluruh peserta remaja. Hal ini tentu memerlukan tindak lanjut berupa memberikan simulasi atau demonstrasi sehingga lebih mudah dipahami oleh peserta. Di samping itu, perlunya kebiasaan dan kontrol yang teratur dapat meningkatkan sikap dan perilaku menjaga kesehatan reproduksi.

Dari kegiatan pengabdian masyarakat ini dapat diketahui harapan dan rekomendasi dari para peserta melalui kuesioner yang dilakukan terkait dengan adanya kelanjutan program serupa. Adapun usaha yang diharapkan untuk dilakukan sebagai kelanjutan dari program ini, yaitu:
1) Menambah pengetahuan tentang penyakit-penyakit dan gangguangangguan yang menyerang kesehatan reproduksi melalui kegiatan-kegiatan serupa

2) Melakukan simulasi atau demonstrasi terkait dengan cara membersihkan organ intim

3) Melakukan pelatihan deteksi dini terhadap kemungkinan adanya penyakit atau gangguan organ reproduksi.

Sementara, ketertarikan dan minat partisipasi peserta terhadap program dan kegiatan yang diadakan oleh tim pengabdian masyarakat Universitas Muhammadiyah Yogyakarta bersama PCNA Ngawen Klaten dapat diamati dalam grafik pada Gambar 5.

Grafik tersebut menunjukkan bahwa mayoritas peserta pengabdian masyarakat memiliki cukup minat dan motivasi untuk mengikuti kegiatan yang membahas mengenai kesehatan reproduksi perspektif Islam dan Medis, baik melalui penyuluhan, sosialisasi, diskusi, simulasi, maupun demonstrasi. Sementara, 29\% peserta sangat berminat dan memiliki motivasi yang tinggi untuk mengikuti kegiatan yang membahas tema kesehatan reproduksi perspektif Islam dan Medis

\section{Sosialisasi dan Diskusi}

Pelaksanaan sosialisasi kesehatan reproduksi ini dilaksanakan sebelum merebak wabah pandemi Covid-19 pada hari Minggu, 09 Februari 2020 (selama satu hari dimulai pukul

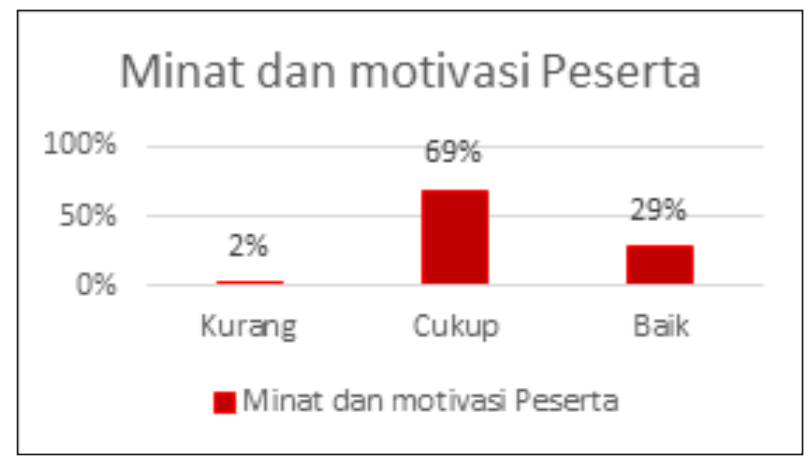

Gambar 5. Grafik Persentase Minat Anggota PCNA mengikuti Kegiatan dengan tema Kesehatan Reproduksi Perspektif Islam dan Medis 
08.00 wib-14.00 wib) yang bertempat di Gedung Aula LKSA Aisyiyah Ngawen Klaten. Sebelum dimulai acara sosialisasi, para peserta diminta untuk mengisi presensi yang telah disediakan. Meskipun kegiatan ini dilaksanakan sebelum pandemi Covid-19, para peserta juga difasilitasi cek kesehatan, berupa cek suhu badan dan cek tekanan darah.

Sosialisasi dimulai dengan pemaparan kesehatan reproduksi perspektif Islam dari narasumber pertama, yaitu Ibu Mir'atun Nisa, M.SI. Pokok-pokok yang disampaikan dalam pemaparan pertama ini adalah: hikmah ajaran Islam bagi kesehatan, hikmah thaharah terhadap kesehatan reproduksi, hikmah berpakaian syar'i terhadap kesehatan reproduksi, hikmah larangan zina dan anjuran menikah, penjelasan tentang haid dan istihadhah.

Kegiatan tersebut dilanjutkan dengan pemaparan dari fasilitator kedua, yaitu Ibu Nur Azizah Indriastuti, S.Kep., Ns., M.Kep. fasilitator kedua menampilkan secara visual berupa anatomi organ reproduksi, organ reproduksi yang sudah rusak atau terkena penyakit, seperti kanker atau tumor. Di samping itu, fasilitator kedua juga menjelaskan cara menjaga kesehatan organ reproduksi yang benar sesuai anjuran dokter.

Setelah dilakukan sesi sosialisasi oleh para fasilitator, dilakukan diskusi dan tanya jawab sebagaimana terdokumentasi sebagai berikut. Tanya jawab berlangsung dengan menarik. Pertanyaanpertanyaan disampaikan oleh beberapa penanya dari berbagai kelompok usia, dari remaja ada 2 penanya, dari kalangan dewasa (belum menikah) 2 penanya dan dari kalangan ibu-ibu 1 penanya. Berikut beberapa hal yang ditanyakan oleh para penanya dirangkum dalam poin-poin berikut
1) Pertanyaan mengenai gangguan selama haid
2) Perbedaan antara mani, wadzi, dan madzi
3) Pertanyaan mengenai keguguran saat mengalami kehamilan

\section{Pemberian Booklet}

Booklet ini mencakup pembahasan kesehatan reproduksi dalam Pandangan Islam dan Kesehatan Reproduksi dalam Pandangan medis. Pembagian booklet dianggap penting

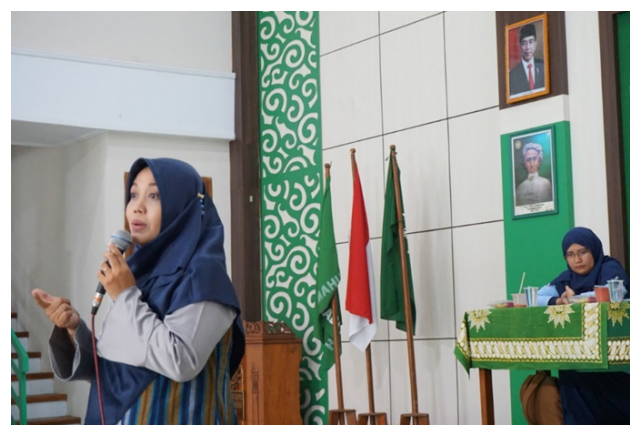

Gambar 6. Sosialisasi Materi Mengenai Kesehatan Reproduksi dalam Islam

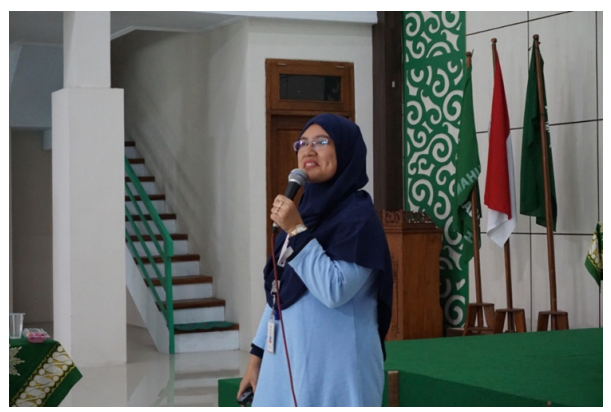

Gambar 7. Sosialisasi Materi Mengenai Kesehatan Reproduksi dalam Medis

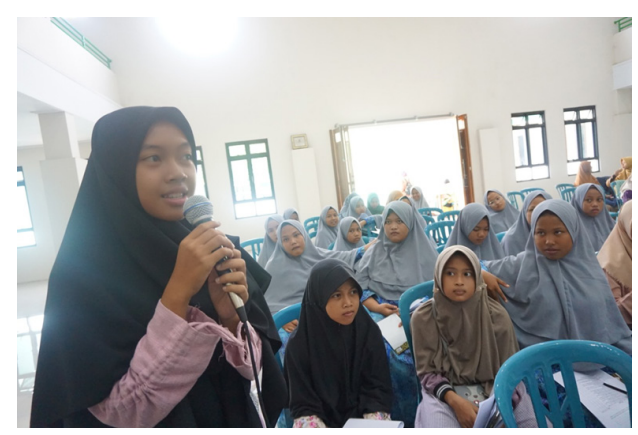

Gambar 8. Sesi Tanya Jawab dan Diskusi

karena tidak semua peserta dapat menangkap penjelasan dengan seksama. Di samping itu, keterbatasan alokasi waktu selama kegiatan menjadikan materi tidak dapat dijelaskan secara komprehensif. Booklet ini juga dapat berfungsi sebagai media pembelajaran bagi para peserta kegiatan mengingat mayoritas peserta berasal dari remaja panti asuhan yang kurang memiliki akses media elektronik, terutama gadget dan media sosial. Hal ini sebagaimana didukung oleh Kemp dan Dayton dalam Acesta (2017) yang mengidentifikasi beberapa manfaat media dalam pembelajaran yaitu: 1) Penyampaian materi pelajaran dapat diseragamkan, 2) Proses pembelajaran menjadi lebih jelas dan menarik, 3) Proses pembelajaran menjadi lebih 


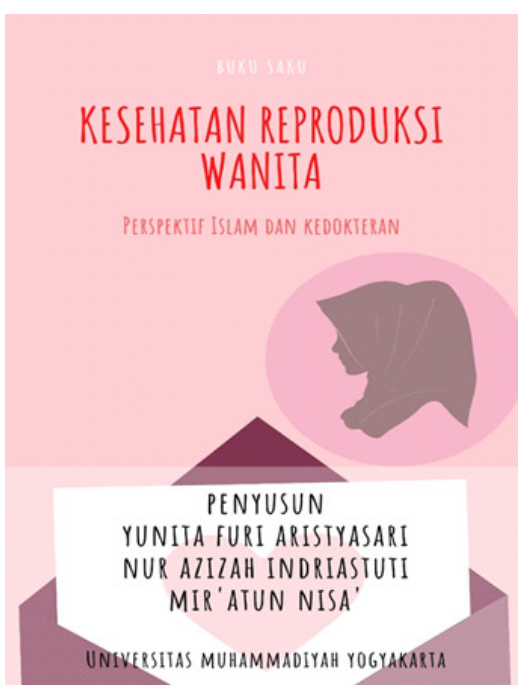

Gambar 9. Booklet Kesehatan Reproduksi Wanita Perspektif Islam dan Kedokteran

interaktif, 4) Efisiensi dalam waktu dan tenaga, dan 5) Meningkatkan kualitas hasil belajar siswa, 6) Media memungkinkan proses belajar dapat dilakukan di mana saja dan kapan saja. Tampilan cover booklet yang telah disusun oleh tim pengabdian dan dibagikan kepada peserta sosialisasi dapat dilihat pada Gambar 9.

\section{Efektivitas Pengabdian dalam Meningkatkan Kesadaran Kesehatan Reproduksi Bagi Remaja}

Pengabdian sebelumnya pernah dilaksanakan di PCNA Ngawen dengan tema Peningkatan Kesiapsiagaan Bencana. Metode yang digunakan adalah sosialisasi dan pemberian buku saku. Pemberian buku saku kesiapsiagaan bencana kepada peserta dilakukan agar peserta dapat lebih memahami, menjadi pengingat, dan pedoman untuk kesiapsiagaan baik secara fisik maupun mental (psikis) sebelum dan setelah bencana terjadi (Diana et al., 2020). Sementara, pentingnya sosialisasi dengan ceramah disertai tampilan-tampilan visual merupakan salah satu metode pendidikan untuk meningkatkan pengetahuan dan pemahaman. Sebagaimana dilakukan oleh (Ramadani \& Budiyono, 2018) yang melaksanakan pengabdian peningkatan pemahaman kesehatan reproduksi yang diperoleh para siswa melalui program penyuluhan dengan menggunakan multi metode yang meliputi ceramah materi, pemutaran video pembelajaran serta simulasi.

\section{SIMPULAN}

Kegiatan Pengabdian masyarakat untuk meningkatkan kesadaran kesehatan reproduksi bagi remaja anggota PCNA Ngawen Klaten telah dilaksanakan dan mendapat sambutan yang positif dari anggota, bahkan apresiasi yang tinggi dari mitra dan pemerintah setempat. Setelah mengikuti kegiatan edukasi berupa sosialisasi dan diskusi terdapat penurunan jumlah peserta yang memiliki pengetahuan kesehatan reproduksi kategori kurang dan cukup. Sebaliknya, hasil post-test aspek pengetahuan menunjukkan peningkatan peserta kategori baik dari sebelum edukasi sebesar $11.00 \%$ responden menjadi $40.40 \%$ responden setelah mengikuti edukasi. Peningkatan aspek pengetahuan peserta didominasi aspek kesehatan repoduksi perspektif Islam. Dalam aspek perilaku menjaga kesehatan reproduksi, dua minggu pasca dilaksanakan edukasi, responden dengan kategori berperilaku baik dari sebelum edukasi yang sebesar $26.10 \%$ meningkat menjadi $33.80 \%$ responden. Hal ini tentu menjadi bahan pelajaran bahwa pendidikan kesehatan reproduksi tidak bisa hanya satu kali atau dua kali saja dilakukan. Proses penyadaran kepada remaja harus dilakukan secara kontinu dan berkesinambungan meliputi sosialisasi pengetahuan dan pemahaman, pelatihan menjaga organ reproduksi, berupa demonstrasi pembersihan organ intim yang benar, demonstrasi deteksi dini terhadap penyakit atau gangguan kesehatan reproduksi, pelatihan thaharah menurut ajaran Islam dan semacamnya. Tentunya, hal ini menjadi harapan para peserta agar kegiatan serupa dilanjutkan dengan melaksanakan sosialisasi tentang gangguan yang rentan terjadi pada remaja, sosialisasi pendidikan seks usia dini menurut medis dan syariat Islam, dan pelatihan kader yang mempromosikan hidup sehat dan islami bebas gangguan reproduksi.

\section{PERSANTUNAN}

Penulis menghaturkan penghargaan dan terima kasih setinggi-tingginya kepada Universitas Muhammadiyah Yogyakarta (UMY) yang telah memberikan dukungan penuh untuk terselenggaranya kegiatan ini melalui Lembaga Penelitian, Publikasi dan Pengabdian kepada 
masyarakat (LP3M). Di samping itu, penulis memberikan penghargaan kepada Pimpinan Cabang Nasyiatul Aisyiyah Ngawen, Klaten, Jawa
Tengah yang telah bersedia menjadi mitra dalam kegiatan pengabdian masyarakat ini.

\section{REFERENSI}

Acesta, A. (2017). Urgensi Media Pembelajaran pada Pendidikan Dasar. Prosiding Seminar Nasional Pendidikan Matematika, 1(1).

Annisa, N. (2012). Preferensi Filantropi Perempuan pada Nasyiatul Aisyiyah di Jawa Timur. Jurnal IndoIslamika, 1(2), 273-309.

BKKBN. (2013). Bimbingan Teknis Kesehaan Reproduksi dan Seksualitas yang Komprehensif. BKKBN.

Cahyorinartri, N. (2018). Motivasi Mahasiswa Berorganisasi di Kampus. Jurnal Psikologi Insight, 2(2), 27-38.

Diana, W., Aristyasari, Y. F., Faizah, R., \& Hartono, E. (2020). Peningkatan Kesiapsiagaan Anggota Nasyiatul Aisyiyah (NA) Cabang Ngawen Klaten terhadap Bencana. ABDIMAS: Jurnal Pengabdian Masyarakat, 3(2), 213-221.

Djunaedi, J. N., \& Listyandini, R. (2020). Pembentukan Kader Remaja dengan Program Rekreasi secara Daring. PKM-P, 4(2), 233-240. https://doi.org/10.32832/pkm-p.v4i2.751

Dwiandriani, Z. Z., \& Nasrullah, M. A. (2017). Penguatan Kesehatan Reproduksi di Komunitas Muslim Kabupaten Banyuwangi. Jurnal Darussalam: Jurnal Pendidikan, Komunikasi dan Pemikiran Hukum Islam, 6(1), 190-208.

Fitriana, H., \& Siswantara, P. (2018). Pendidikan Kesehatan Reproduksi Remaja di SMPN 52 Surabaya. The Indonesian Journal of Public Health, 13(1), 110-121. https://doi.org/10.20473/ijph. v13i1.2018.110-121

Hasanah, H. (2017). Pemahaman kesehatan Reproduksi bagi Perempuan: Sebuah strategi Mencegah Berbagai Risiko Masalah Reproduksi Remaja. Sawwa: Jurnal Studi Gender, 11(2), 229-252.

Iryanti, S. S., \& Rachmawati, M. (2019). Islamic Parenting: Upaya Mewujudkan Generasi Muslim Millenial Berkemajuan di Nasyiatul Aisyiyah Depok. Prosiding Abdimasmu, 1(1), 323-330.

Nasyiatul 'Aisyiyah. (2016). Profil Nasyiatul 'Aisyiyah. Nasyiatul 'Aisyiyah Muhammadiyah. http://m. muhammadiyah.or.id/id/content-89-det-na.html

Ramadani, S. D., \& Budiyono, A. (2018). Peningkatan Pemahaman Kesehatan Reproduksi dalam Bingkai Islam Bagi Siswa Sekolah Dasar di Desa Palalang Kecamatan Pakong, Pamekasan. Seminar Nasional Hasil Pengabdian Kepada Masyarakat, 2, 261-266.

Rizal, F. (2015). Hak-Hak Kesehatan Reproduksi dalam Islam dan Aborsi. Tafáqquh: Jurnal Penelitian Dan Kajian Keislaman, 3(2), 37-56.

Shobahiya, M. (2016). Meretas Problem Perkaderan 'Aisyiyah dan Alternatif Solusi Berbasis Potensi. Tajdida: Jurnal Pemikiran Dan Gerakan Muhammadiyah, 13(2), 125-135.

Sinaga, A. S., Buaton, A., \& Sitorus, M. A. (2020). Knowledge and Exposure Information Of Adolescents about Reproductive Health. Contagion: Scientific Periodical Journal of Public Health and Coastal Health, 1(2), 97-107. 